\title{
125 Г. ИСТОРИЯ НА ОРГАНИЗИРАНОТО БОЛНИЧНО ХРАНЕНЕ
}

\section{П. Цонов}

Oar анитарният закон е утвърден с Указ 545 от княз Фердинанд. Това става на 29 ноември 1888 г. на заседение на обикновеното Народно събрание, на неговата втора сесия. Санитарният закон е преподписан от министъра на вътрешните дела Стефан Стамболов. С държавен печат Законът е регистриран под №207 от 10 януари 1889 г. В него, в три части се залагат гражданските санитарни права̀ и задължения.

Първата част обхваща права̀та и задълженията на общите и местни санитарни власти. Върховният медицински съвет (най-високото съвещателно санитарно тяло по всички санитарни въпроси в държавата), дейностите на окръжните и околийските лекари, общинските лекари, окръжните хигиенически съвети, лекари, ветеринарни лекари, фелдшери, баби-акушерки. Втората част е предназначена за болниците в Княжеството, които са под надзора на министьра на вътрешните дела.

Третата част засяга работата на аптеките и наказанията по повод нарушенията в упражняването на медицината, ветеринарството, аптекарството, акушерството и зъболекарството. Нарушеннията се съдят по общите закони на страната, но при задължителното участие и зачитане мнението на Върховния медицински съвет.

На основание на чл. 117 от Санитарния закон се създава Правилник за вътрешната санитарна служба в държавните болници, а в чл. 134 от Санитарния закон е предвидено създаване на Разписание на порциите, изработвано от Върховния медицински съвет и утвърждавано от министъра на вътрешните работи. В това разписание се предвиждат четири степени на храна:

- строга диета, според която болните не получават за храна нищо;

- диета, при която на болния се дава три пъти на ден по една говежда супа или бульон, или мляко по 900 грама, дадено на три пъти;

- обикновена храна, предлагана в три вида порции: пьрва - супа, 120 гр. месо, 200 гр. зарзават и 250 гр. бял хляб; втора - супи, 500 гр. бял хляб, 250 гр. месо, 400 гр. зарзават; трета - супи, 750 гр. бял хляб, 400 гр. месо, 500 гр. зарзават;

- извънредната храна се изменя според времето през годината и се дават като една или две прибавки в ден. Извънредната храна се състои от:

- супи, които биват кисели и благи. Приготвят се от кокошка, пиле, агне или риба. Количеството, което се отпуща за една супа са 1 четвърт от кокошка, половин пиле, 150 гр. агнешко или риба;

- печено - от говеждо, свинско, агнешко месо, кокошка, пиле или риба в количества: 1/4 от кокошка или половин пиле, 150 гр. агнешко или риба. Кюфтетата се приготвят от 150 гр. кълцано месо, разделено на две кюфтета, прибавят се 10 гр. масло, 10 гр. брашно, 10 гр. хляб, сол и лук;

- млека - прясно, бито или подквасено в количество до 300 гр., предлага се и под формата на мляко с ориз, грис и 200 гр. към кафето;

- чай - с 3 гр. чай, 20 гр. захар и 300 гр. вода;

- кафе - 75 гр., с 5 гр. кафе и 15 гр. захар;

- сирене - порцията е 80 гр., а кашкавала - 50 гр.;

- маслини - порцията е 100 гр.;

- яйцз - отпускат се по 1 или 2 на ден; за пържени яйца се отпускат по 10 гр. краве масло на яйце;

- овощчия - за една порция се допуска 150 гр. ябълки, круши, грозде, 1 портокал или 1 лимон; салата - за една порция се допуска 150 гр. зеленчук, 20 гр. оцет, 10 гр. дървено

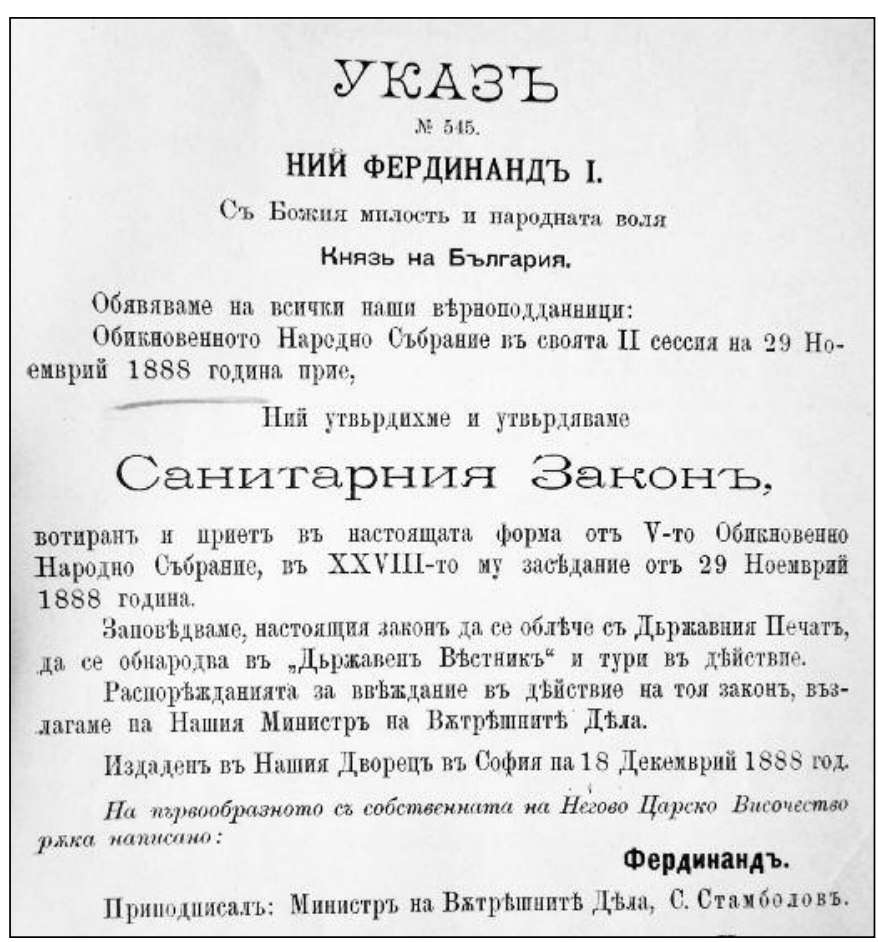

масло и 5 гр. сол;

- питиета - вино бяло или червено обикновенно, ракия или бира. Според усмотрението на лекаря на болния се дава дневно от 200 до 300 гр. вино, 500 гр. бира и ракия до 50 гр.

Часовете за раздаване на храната на болните е: сутрин - между 5-7 часа или 7-8 часа зиме; обяд - между 11-12 и вечер - между 6-7 лете и 5-6 часа зиме.

По преценка на лекаря са дават до две постни ястия.

„Требвателният лист“ за храната на болните е ежедневен. В него се отбелязват: павильона, отделението, стаите, номера на легло, вида хранене и отпуснатата извънредна храна. Отбелязва се желаната замяна на месна храна с постна храна. „Требвателният лист“ се подписва от лекаря и фелдшера. Във формуляра „Дневна ведомост“ се посочват: леглата за мъже, жени и военни, пълните и празни легла, вида храна за закуска, обяд и вечеря. „Дневна ведомост“ се подписва от лекар. Санитарният закон от 1888 г. фактически възлага за първи път у нас отговорности на държавните административни власти. Това става чрез поемане на държавни функции от окръжни, околийски и общински административни управления чрез лекарите, работещи в тях. Санитарният закон регламентира и правото на безплатно лечение за определени категории държавни служители, ученици, бедните и болните от заразни и венерически болести. Формираните Окръжни хигиенически съвети стават авторитетни обществени органи, които решават водещите хигиенни проблеми. Създава се цялостна система на здравна администрация, подпомогната от „санитарно-полицейски отделения“, имащи определени контролни функции. Социално-здравното законодателство бележи своето начало след Закона за опазване на общественото здраве (1903). Това става със Закона за закрила на женския и детски труд (1905) и Закона за подпомагане на държавните работници в случаи на инвалидност и заболяване (1906). Санитарният закон от 1888 г обаче стои в основата на здравното дело в България. Този закон е едно от важните дела на правителството на Стефан Стамболов. 